\title{
Sedimentation style of a Pleistocene kame terrace from the Western Sudety Mountains, S Poland
}

\author{
Małgorzata Pisarska-Jamroży ${ }^{1}$, Katarzyna Machowiak ${ }^{2}$, \\ Dariusz Krzyszkowski ${ }^{3}$ \\ ${ }^{1}$ Adam Mickiewicz University, Institute of Geology, Maków Polnych 16, 61-606 Poznan, Poland; \\ e-mail: pisanka@amu.edu.pl \\ ${ }^{2}$ Poznań University of Technology, Faculty of Computing Science and Management, Institute of Civil Engineering, \\ 60-965 Poznań; e-mail: kamachow@amu.edu.pl \\ ${ }^{3}$ University of Wrocław, Institute of Geology, Plac Maksa Borna 9, 50-204 Wrocław; \\ e-mail: dariusz.krzyszkowski@ing.uni.wroc.pl
}

\begin{abstract}
The depositional conditions of kame terraces in a mountain valley were analysed sedimentologically and petrologically through a series of kame terraces in the Rudawy Janowickie mountains. The kame terraces comprise five lithofacies associations. Lithofacies association GRt, Sp originates from deposition in the high-energy, deep gravel-bed channel of a braided river. Lithofacies association GC represents a washed out glacial till. Probably a thin layer of till was washed out by sandy braided rivers (Sp). The fourth association (Fh, Fm) indicates a shallow and quite small glaciomarginal lake. The last association (GRt, GRp) indicates the return of deposition in a sandy-bed braided channel. The petrography of the Janowice Wiekie pit and measurements of cross-stratified beds indicate a palaeocurrent direction from $\mathrm{N}$ to S. The Janowice Wielkie sedimentary succession accumulated most probably during the Saalian (Odranian, Saale I, Drenthe) as the first phase of ice-sheet melting, because the kame terrace under study is the highest one, 25-27 $\mathrm{m}$ above the Bóbr river level. The deposits under study are dominated by local components. The proglacial streams flowed along the margin of the ice sheet and deposited the kame terrace. The majority of the sedimentary succession was deposited in a confined braided-river system in quite deep channels.
\end{abstract}

Keywords: kame terrace, confined braided rivers, lithofacies analysis, sediment-petrographical analysis, Pleistocene, Sudety Mountains

\section{Introduction}

The deposits under study are situated in the Janowice Wielkie at $422 \mathrm{~m}$ a.s.l. (Figs. 1, 2), on the right-hand side of the Bóbr river (395-400 m a.s.1.). The sediments overlie the north-eastern part of the Carboniferous Karkonosze granite and the Izera Massif of the Sudety Mountains. The substratum of the gravel pit and the Quaternary in its surroundings consists of the
Karkonosze granite. Further to the North and the West, these granites with small crystals are commonly replaced by porphyritic ones containing large amounts of orthoclase and enclosures.

To the north of the gravel pit, rocks of the metamorphic Kaczawa Unit form a large belt in which greenstones dominates. The metamorphosed Karkonosze granite is exposed east and south-east of the gravel pit. These rocks in- 


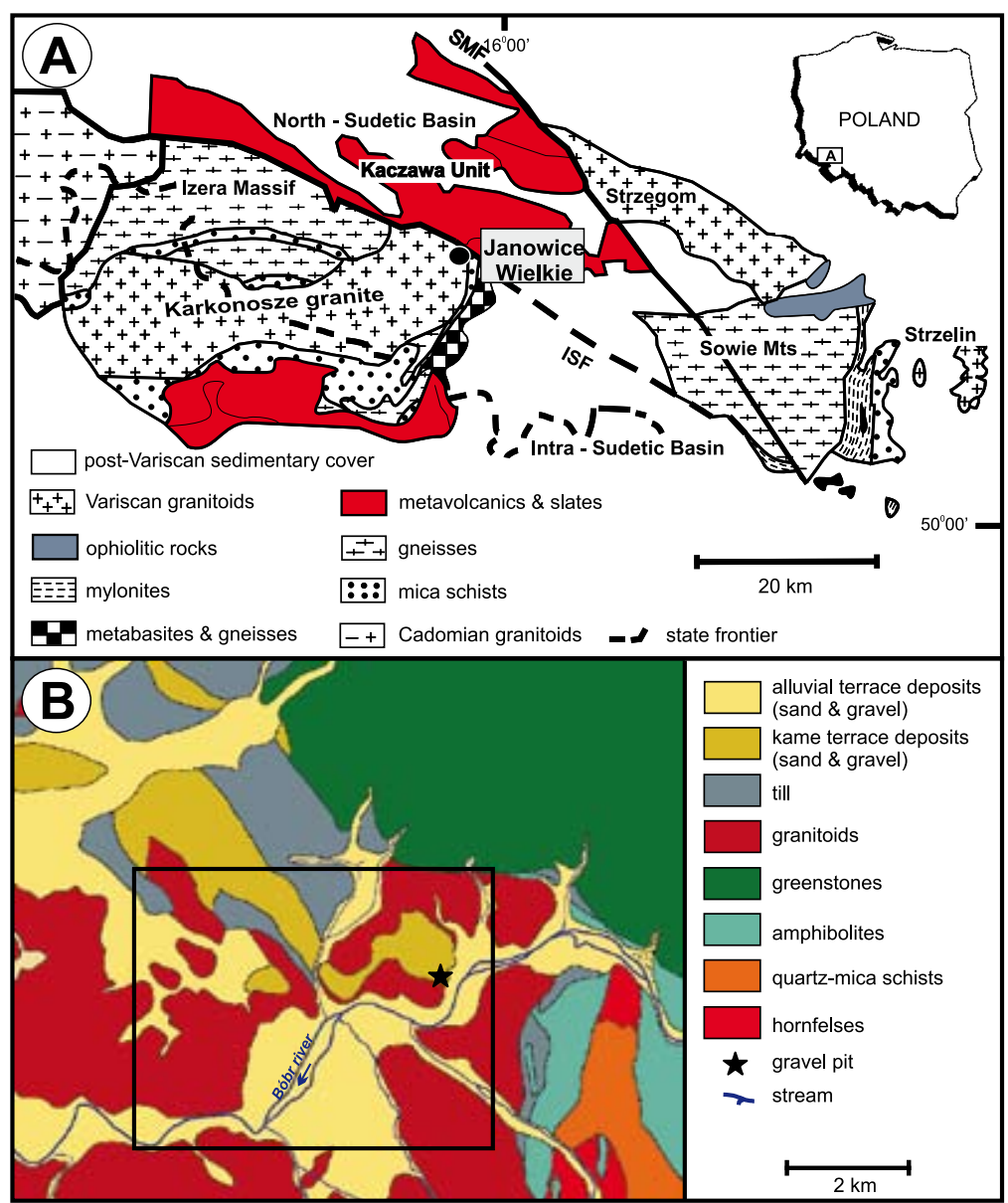

Fig. 1. A - Geological map of the Sudetes Mountains (simplified after Aleksandrowski et al., 1997) with location of the gravel pit in Janowice Wielkie. ISF $=$ Intra-Sudetic Fault, SMF = Sudetic Marginal Fault; B - Geological map of the area around Janowice Wielkie (after Szałamacha, 1956, 1969; partly modified). The rectangle shows the area presented in Fig. 2A.

clude several types of postdiaphtoretic amphibolites, quartz-chlorite schists, quartz-sericite schists and phyllites. Further to the East, breccias and conglomerates of the Intra-Sudetic Basin crop out (Fig. 1A).

During the Odranian (Saale I, Drenthe), one of the ice-sheet lobes flowed into the Bóbr valley from the West. When the ice sheet melted, a kame terrace was deposited between the northern wall of the Bóbr valley and the ice lobe. The kame terrace extends for $4 \mathrm{~km}$ along the northern Bóbr wall, is 250-600 m wide and has an elevation of $25-27 \mathrm{~m}$ above the Bóbr river level (422 $\mathrm{m}$ a.s.l.). The Janowice Wielkie gravel pit is located in the eastern part of the terrace. Three levels of kame terrace are known from the Bóbr river valley, which indicates that the deglaciation took place during several phases (Jahn, 1969). In the geological literature, the term 'kame terrace' is most commonly used to indicate deposits of glaciofluvial streams that flow(ed) between the slope of an ice sheet (or ice lobe) and a valley wall. These kame ter-
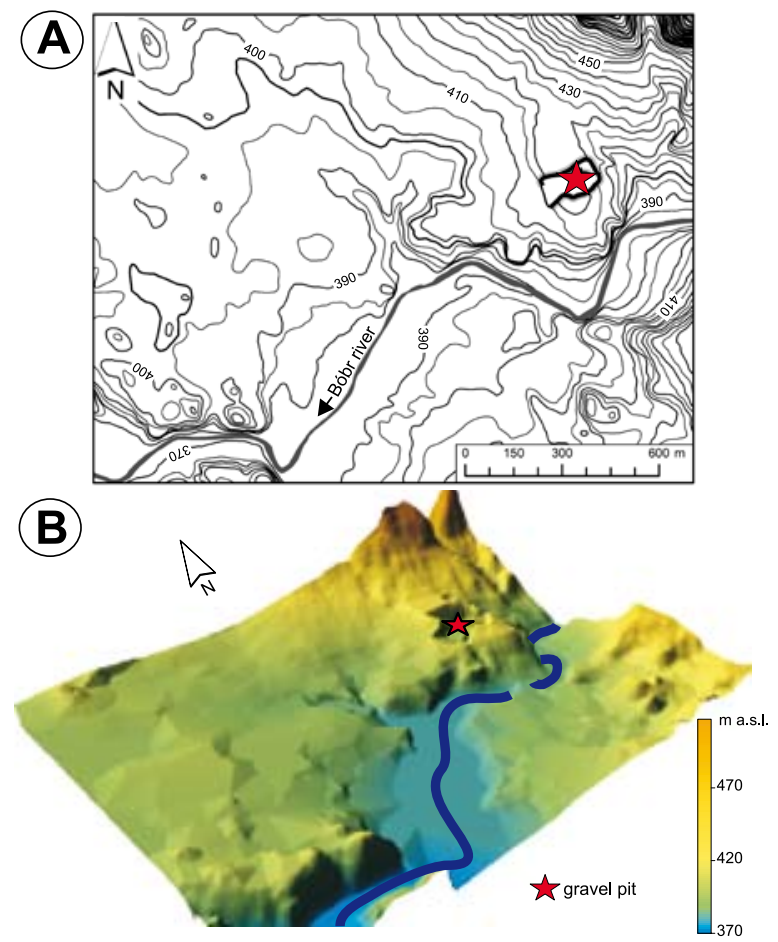

Fig. 2. A - Hypsometric map of the area around the Janowice Wielkie gravel pit; B - Shaded perspective images of the terrain's surface. 
races look like plateaus with an irregular upper surface.

Several kame terraces in mountain valleys have been described before, among others by Jahn (1969) for the Bóbr valley, by Walczak $(1957,1968)$ for valleys in the Kaczawa Mountains, the Bardzkie Mountains and the Bóbr valley, by Chachaj et al. (1984) for valleys in the Kaczawa Mountains, by Szczepankiewicz \& Szponar (1978) for the Sudetic Foreland, and by Lindner (1970) for the Holly Cross Mountains. On the basis of more recent Polish sedimentological investigations, some plateaus that were previously interpreted as kame terraces in the Sudety Mountains are now interpreted as erosional remnants of a wide alluvial plain or delta along the margin of a sedimentary basin (Krzyszkowski \& Ibek, 1998; Kowalska, 2002).

\section{Methods}

The sedimentological analysis of the Janowice Wielkie gravel pit included measurement of the mean grain size and the maximum particle size (MPS), the type of stratification and petrographical identification of 200 clasts of the $5-10 \mathrm{~cm}$ fraction. The gravel fabric and the petrographical composition of the sediments were used to reconstruct the palaeocurrent direction. The average channel depth of the braided rivers was calculated, following Mohrig et al. (2000), as the double height of trough deposits.

The lithofacies distinguished are coded following Zieliński (1992) and Pisarska-Jamroży

Table 1. Sedimentary lithofacies code used (after Maizels, 1993; Zieliński, 1992; partly modified).

\begin{tabular}{ccc}
\hline Code & Texture & Structure \\
\hline GC & $\begin{array}{c}\text { cobbly gravel } \\
(64-256 \mathrm{~mm})\end{array}$ & - \\
GPp & $\begin{array}{c}\text { pebbly gravel } \\
(4-64 \mathrm{~mm})\end{array}$ & planar cross-stratification \\
GRt & $\begin{array}{c}\text { granule gravel } \\
(2-4 \mathrm{~mm})\end{array}$ & $\begin{array}{c}\text { trough cross-stratification } \\
\text { planar cross-stratification }\end{array}$ \\
GRp & sand & planar cross-stratification \\
Sp & $(0,0625-2 \mathrm{~mm})$ & horizontal lamination \\
Fh & silt \& clay & massive \\
Fm & $(<0,0625 \mathrm{~mm})$ & \\
\hline
\end{tabular}

(2006) (Table 1). The various deposits grouped into lithofacies and lithofacies associations.

\section{Characteristics of the lithofacies associations}

Gravels of various size dominate the deposits in the Janowice Wielkie gravel pit, where five lithofacies associations have been recognized (Figs. 3, 4):

- trough cross-stratified fine-grained gravel (granules) and planer cross-stratified sand (GRt, Sp),

- coarse-grained gravel (cobbles) lag (GC),

- planar cross-stratified sand (Sp)

- horizontally-laminated and massive silt (Fh, Fm),

- trough and planar cross-stratified finegrained gravel (granules) (GRt, GRp),

\section{Lithofacies association GRt, $\mathrm{Sp}$}

\section{Description}

The lowermost lithofacies association (GRt, Sp) (Figs. 3A, 4) has a thickness of $\sim 4 \mathrm{~m}$ and consists of cross-stratified fine-grained gravels and sands. Some beds contain an admixture of medium-sized gravel. Subordinate amounts of planar cross-stratified fine- and mediumgrained gravel (GRp \& GPp) with an openwork texture are present (Fig. 2C).

The beds constituting lithofacies GRt have a thickness of $2.8 \mathrm{~m}$ and an average extent of $200 \mathrm{~m}$. The lower and upper boundaries are mostly gradational. The gravel is matrix-supported (MPS $=8 \mathrm{~cm}$ ), and the matrix consists of medium- and coarse-grained sand. The GRt laminae $\operatorname{dip} 20^{\circ}$ towards the South. The average depth of the troughs amounts to some 1.5 $\mathrm{m}$.

Lithofacies Sp is sheet-like, with a thickness $1.5 \mathrm{~m}$ and an average extent of $200 \mathrm{~m}$. The lower and upper boundaries are gradational. The sand is coarse- to medium-grained, occasionally with fine-grained gravel in the lower part of the beds (normal grading). The Sp laminae $\operatorname{dip} 20^{\circ}$ towards the SSE. 

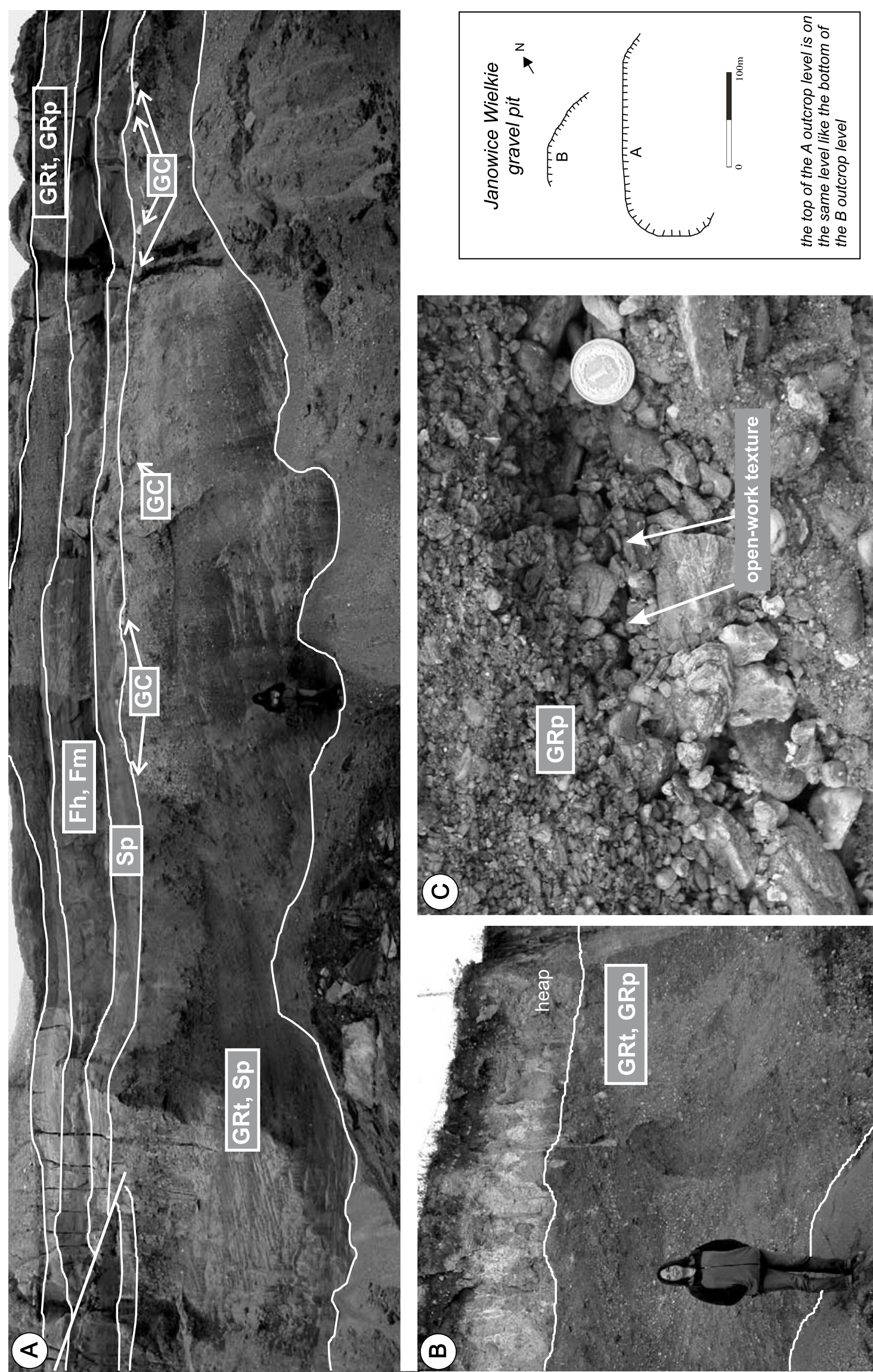

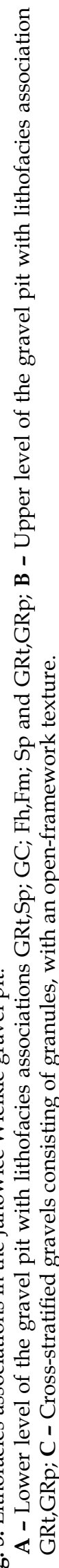
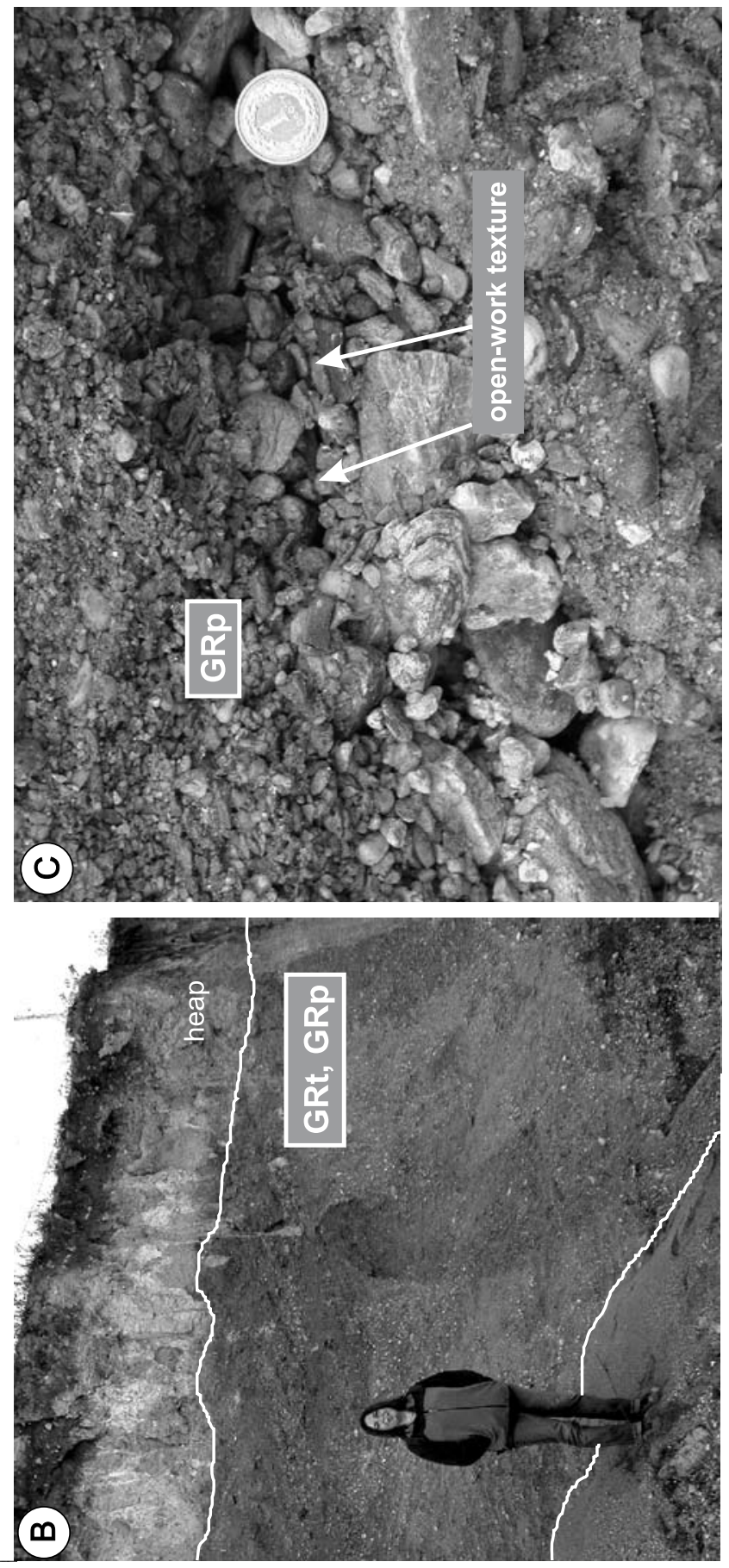

in 


\section{Interpretation}

The sets of large-scale cross-stratified granule-sized gravels and coarse-grained sands record high-discharge bars in braided channels. The thick lithofacies of trough cross-bedded deposits may represent a high-energy current which eroded extensive, shallow trough-like pools (Giżejewski, 1973). Such pools were then filled with poorly-sorted sediment. The poor sorting suggests a suddenly waning current in the braided river. The average depth of these braided channels was $2.4 \mathrm{~m}$. Similar large-scale troughs have been described from several other sediments of large braided rivers (Forbes, 1983; Morison \& Hein, 1987; Zieliński, 1992). In places where the current was relatively shallow during waning flood phases, strata of planar cross-sets (lithofacies Sp) were deposited. The thick strata and steep angle of the laminae $\left(20^{\circ}\right)$ imply progradation of high transverse bars, which are typical of braided-river systems.

The entire lithofacies association was deposited by a high-energy current in a braidedriver channel. The open-work texture in the upper part of lithofacies GRt resulted from a diminishing discharge of the turbulent current (cf. Costa, 1988), what caused fine-grained material to settle into the pores between the gravel particles (cf. Beschta \& Jackson, 1979; Frostrick et al., 1984). Consequently, clogging occurred in the top layer and prevented further downward infiltration of fines, thus producing a layer of gravel without matrix at the bottom. Thin beds of open-work gravel are quite common in sandur deposits (McDonald \& Banerjee, 1971; Smith, 1974; Maizels, 1977, 1987, 1993, 1997; Fraser \& Cobb, 1982; Hein, 1984, Russell \& Marren, 1998; Pisarska-Jamroży, 2006). The average depth of the braided streams was $\sim 3$ $\mathrm{m}$. The palaeocurrent direction measured for association GRt, Sp suggests that the sediment was transported from NNW to SSE (Figs. 2, 3).

\section{Lithofacies association GC}

\section{Description}

Lithofacies association GC (Figs. 3A, 4) is dominated by angular granite (granitoid) clasts, which form a horizon separating the Sp and GRt lithofacies its horizontal extent in the outcrop is $\sim 200 \mathrm{~m}$.

\section{Interpretation}

The angular coarse-grained gravel is an erosional remnant of a glacial till, probably a flowtill. The degree of water saturation in flowtill tends to be much higher than in other tills, and it was therefore washed out easily. The flowtill, which represents a local feature, started probably to be washed out by the braided river already during deposition.

\section{Lithofacies association $\mathrm{Sp}$}

\section{Description}

Lithofacies Sp includes consists of coarseand medium-grained sands with planar crossstratification (Fig. 3A). The beds are $0.3 \mathrm{~m}$ thick and have a $200 \mathrm{~m}$ horizontal extent. Their lower and upper boundaries are usually gradational. The laminae of this lithofacies dip $20^{\circ}$ towards the SSW.

\section{Interpretation}

The depositional environment of this lithofacies was the same as that of lithofacies $S p$ in association GRt, Sp: large transverse bars in a sand-bed braided river.

\section{Lithofacies association $\mathrm{Fh}, \mathrm{Fm}$}

\section{Description}

The assemblage of horizontally stratified and massive silts (association Fh, Fm) is $1 \mathrm{~m}$ thick and has a horizontal extent of at least $200 \mathrm{~m}$ (Figs. 3A, 4). The lower boundary is deformed (occasional load structures), whereas the upper boundary is sharp, due to erosion. In the basal part of these lithofacies, wavy and flaser structures occur locally.

\section{Interpretation}

Lithofacies association Fh, Fm was deposited in an ephemeral, shallow and small glaciomarginal lake. The small grain size, the thin character of the beds, and the lack of crossstratification indicate deposition from suspen- 


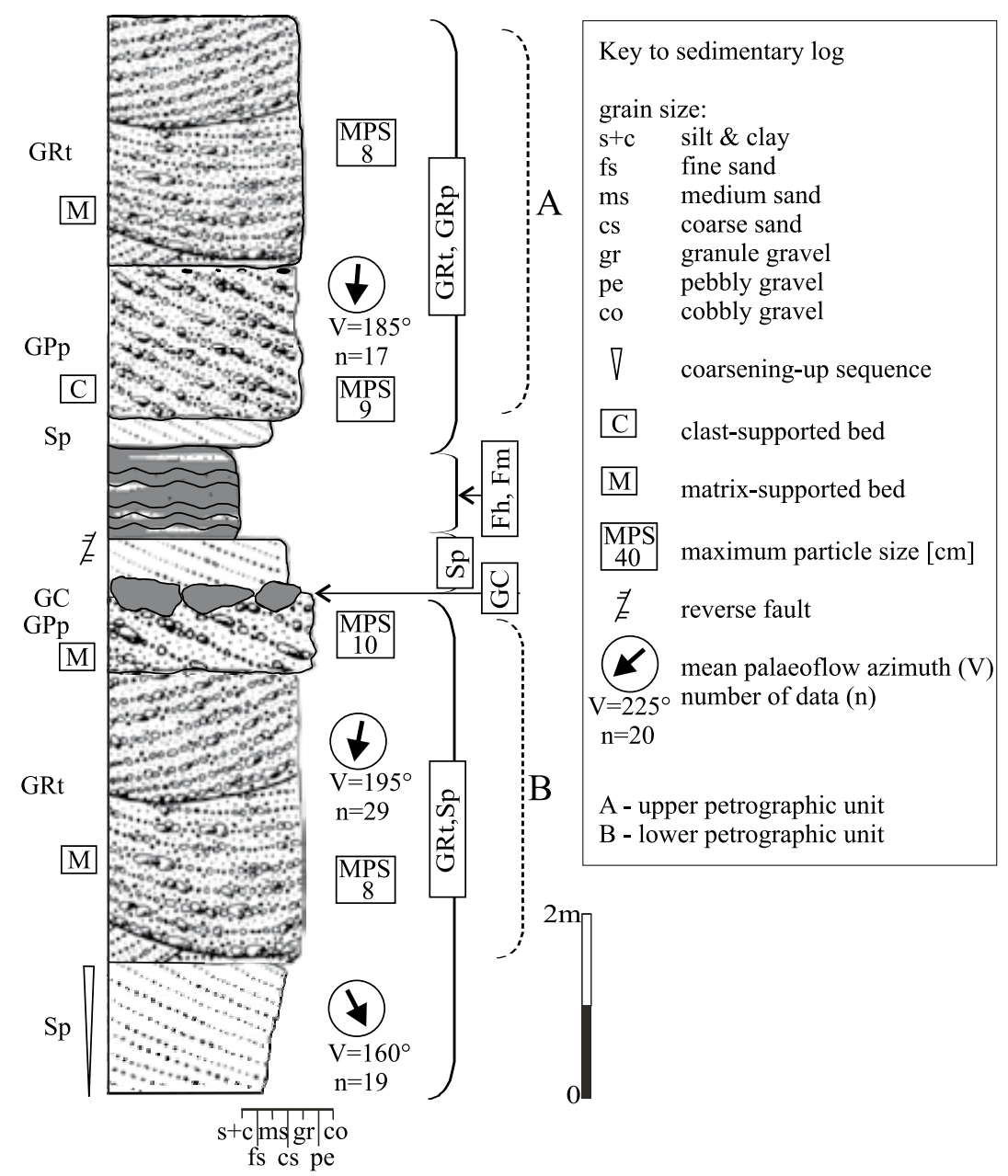

Fig. 4. Sedimentary log from the Janowice Wielkie pit.

sion settling. Load structures in the basal part of lithofacies $\mathrm{Fh}$ developed due to reversed density gradients in the soft, water-saturated sediments.

\section{Lithofacies association GRt, GRp}

\section{Description}

Lithofacies GRt forms a sheet-like unit, up to $2.8 \mathrm{~m}$ thick, with an average lateral extent of $\sim 100 \mathrm{~m}$. Its lower boundary is sharp, erosional and the upper boundary is anthropogenetically disturbed. The gravel (MPS $=8 \mathrm{~cm}$ ) is matrix-supported; the matrix consists of finegrained sand. The average depth of the troughs amounts to $1.2 \mathrm{~m}$.

The beds of lithofacies GRp are also sheetlike, with a total thickness of $2 \mathrm{~m}$ and a minimum horizontal extent of $2 \mathrm{~m}$. The lower boundary is gradational, whereas the upper boundary is sharp (erosional). The gravel (MPS $=9 \mathrm{~cm}$ ) is clast-supported; the matrix consists of medium-grained sand. The cross-laminae $\operatorname{dip} 20^{\circ}$ towards the South.

\section{Interpretation}

Lithofacies GRt represents, in this lithofacies association, a high-energy current which eroded extensive, shallow, trough-like pools like described for lithofacies association GRt, Sp. The average depth o the channels was the same as in association GRt, Sp, viz. $2.4 \mathrm{~m}$. In places where the current was shallower, strata forming planar cross-sets (lithofacies GRp) were deposited. The thickness of the beds and the steep angle of the laminae $\left(20^{\circ}\right)$ imply progradation of large transverse bars. Deposition took place from high-energy currents, probably during one or more phases of increasing 


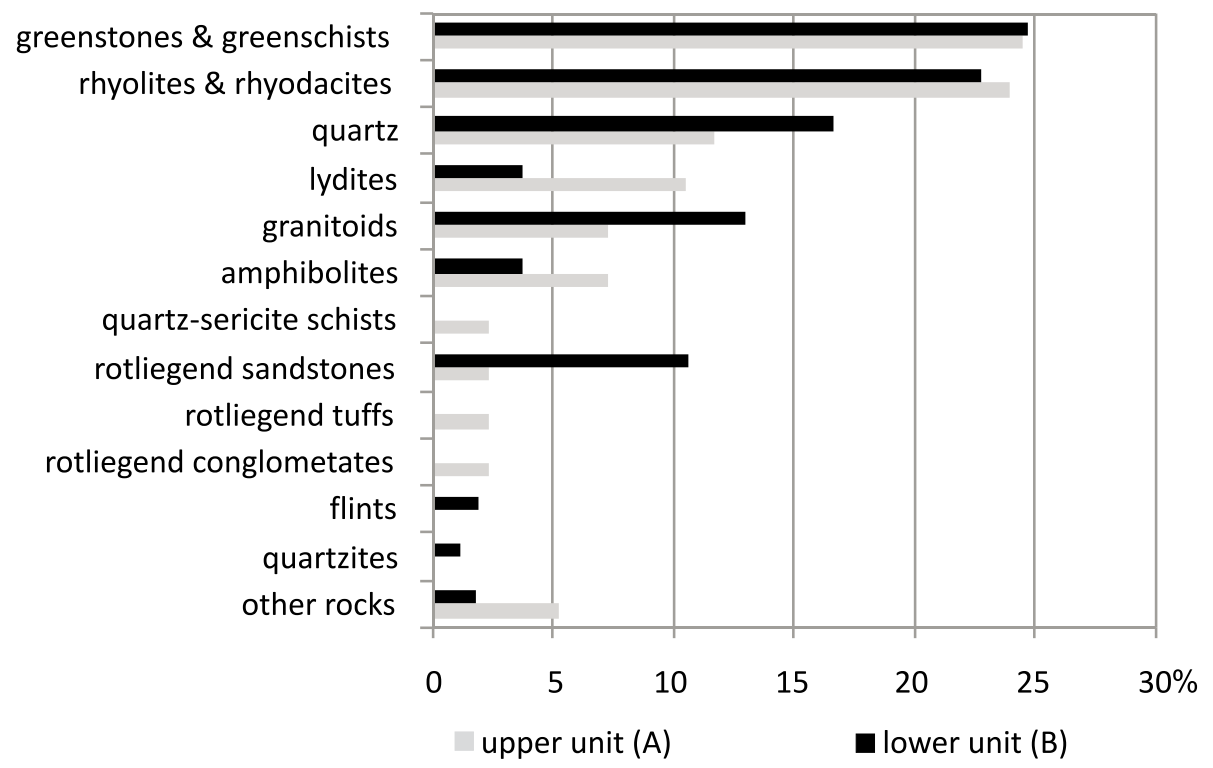

Fig. 5. Petrographical composition of the gravels in the upper (A) and lower (B) units.

discharge, in the channels of a coarse-grained braided river. The orientation of the gravelly cross-stratified sets (lithofacies GRp) indicates palaeocurrent directions from North to South (Fig. 3).

\section{Composition and source of the gravel}

\section{Description}

Gravels were collected from two units of the gravel pit for analysis of their source rocks, viz. from a lower unit (A), and an upper unit (B) (Fig. 5).

Unit A contains predominantly local rocks derived from the Kaczawa Unit, including both the Variscan basement and the post-Variscan cover (which occur maximally some $20 \mathrm{~km}$ to the North and East: see Fig. 1A).

The largest group is represented by massive greenstones and greenstone schists (present $\sim 5$ $\mathrm{km}$ to the $\mathrm{N}$ and NE: see Fig. 1B). The second group is formed by rhyolites and rhyodacites from the North-Sudetic Basin (Fig. 1), and contains also lydites, which are also commonly present in the Kaczawa Unit. Moreover, local material is present in the form of Karkonosze granitoids, with dominance of angular grains $(7.3 \%)$. The cobble horizon (facies GC) between the GRt, Sp and Sp associations consists also of granitoids. The profile contains also in addition amphibolite pebbles (7.3\%), of which with the source area is the eastern cover of the Karkonosze granite $(\sim 500 \mathrm{~m}$ from the study site, see Fig. 1A). The remaining pebbles are mainly derived from the Kaczawa Unit (sandstones, Rotliegendes conglomerates, tuffs with lapilli, metatrachites, quartz-sericite and graphite schists). Scandinavian erratics (2\%) are rare; they are represented by gneisses, limestones, flint and quartz.

Unit B shows less diversity. The largest group consists of greenstones and acidic volcanic rock from the Kaczawa Unit. The percentage of amphibolites from the eastern cover of the Karkonosze granite amounts to only 3.7\%. Scandinavian comprise only up to $2 \%$.

\section{Interpretation}

The similarity in the gravel composition from units $A$ and $B$ is striking. Both units consist almost exclusively of local rocks (greenstone, greenschists, rhyolites, rhyodacites, quartz), with a small component of Scandinavian rocks. Comparison with potential source rocks in the neighbourhood indicates that almost all gravel travelled maximally $20 \mathrm{~km}$ ), and that the palaeocurrent direction was from $\mathrm{N}$ to $\mathrm{S}$. 

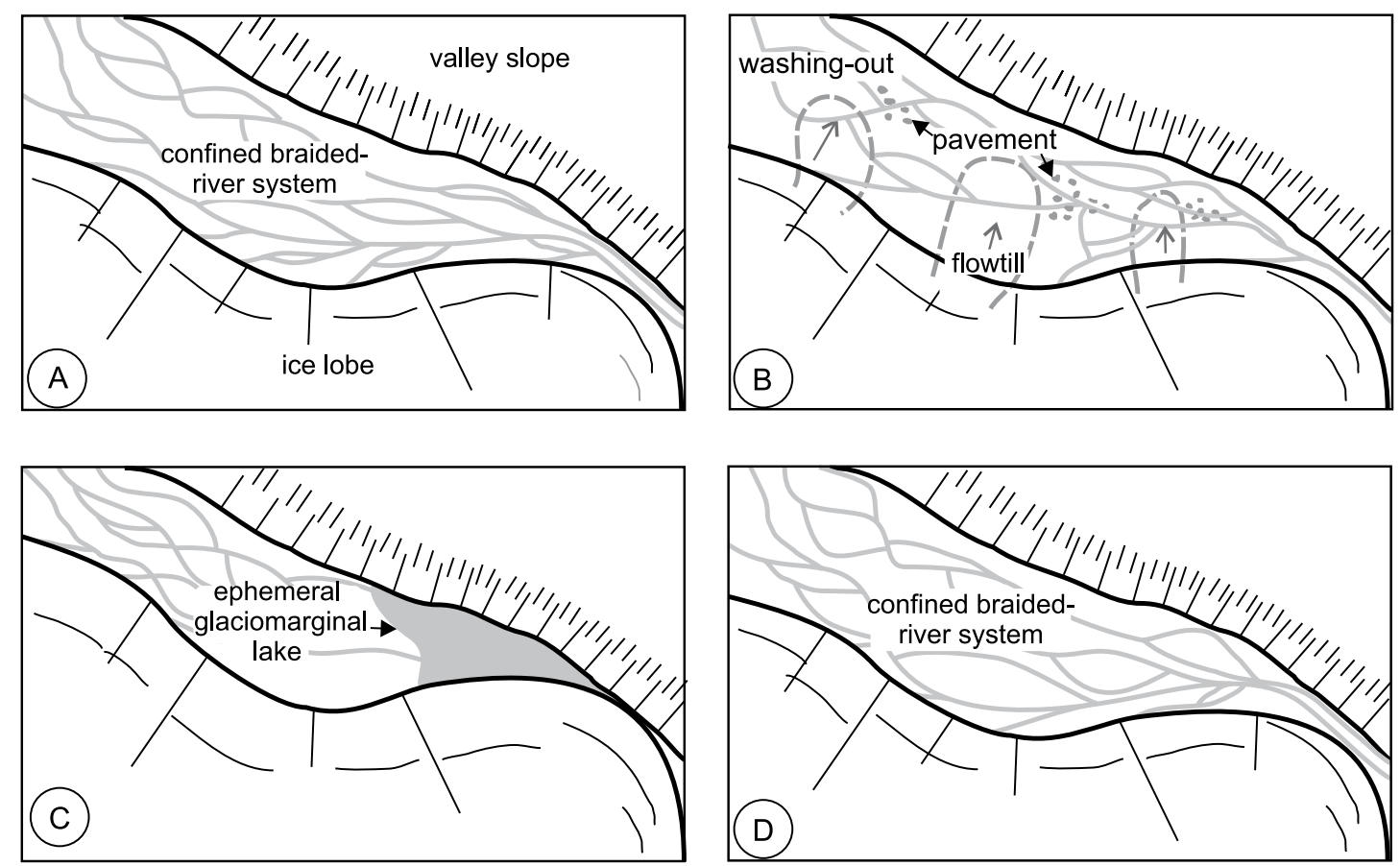

Fig. 6. Schematic model for the kame-terrace sedimentation. A - High-energy, deep channel system of a confined braided river; B - Gravity-induced flowtill and its fluvial reworking; C - Deposition in an ephemeral, small glaciomarginal lake; D - Return to a high-energy, deep channel system of a confined braided river.

\section{Final remarks and conclusions}

The sediments in the gravel pit at Janowice Wielkie are interpreted to build up a kame terrace. During the Odranian glaciation in the Bóbr valley, the proglacial streams flowed along the margin of an ice-sheet lobe. When the ice melted, meltwater built the kame terrace on the northern wall of the river valley. This took probably already place during the first phase of ice-sheet melting, because the kame terrace is the highest one, at an elevation of 25-27 $\mathrm{m}$ above the Bóbr river level (Jahn, 1969, described three levels with kame terraces in this valley).

The presence of deep channels in a braidedriver system indicates that the conditions were uncommon: a braided-river system confined by the ice margin at one side and by a steep mountain slope format the other side. Similar deep channels occur in "pool deposits produced at the junction of channels" in gravelly braided-river systems (Siegenthaler \& Huggenberger, 1993), but the existence of a $200 \mathrm{~m}$ wide channel junction is rather questionable in our opinion. The shallow, trough-like pools were rather produced by a high-energy current with a large erosive capacity. The bottoms of the troughs were locally washed-out and the resulting pools were filled with poorly-sorted sediment when the velocity of the braided streams diminished.

A 4-stage model is proposed for the development of this kame terrace (Fig. 6). The proglacial hydrological conditions changed quickly due to diurnal and seasonal changes in ablation rate, as indicated by differences in grain size. Lithofacies GC probably is a quite thin layer of flowtill, washed out by local currents that built lithofacies $S p$. The presence of a remnant of this flowtill) indicates a lower discharge and maybe the shift of a channel. The next lithofacies association (Fh, Fm) was deposited by a very shallow, low-energy current and by settling from suspension. This took place in a shallow glaciomarginal lake, which formed because an ice-sheet lobe dammed off the valley. The subsequent phase of sedimentation meant a return to the confined braidedriver system.

The lower and upper units from which the gravel was analysed show a palaeocurrent direction from $\mathrm{N}$ to $\mathrm{S}$; they are dominated by local rocks (the source was maximally $20 \mathrm{~km}$ 
away). The characteristics of the gravel from the Janowice Wielkie site cannot be correlated with those from the Sudetic Foreland (Badura et al., 1998; Krzyszkowski \& Allen, 2001; Krzyszkowski \& Czech, 1995) due to the large differences in petrographical composition. Probably, however, they can be petrographically correlated with sediments from the Wałbrzych Foothills (Krzyszkowski \& Stachura, 1998), the Bolków Foothills (Migon et al., 1998) and the southern part of the Kaczawa Mountains (Kowalska, 2002).

\section{Acknowledgements}

The authors thank Tomek Zieliński and two unknown referees for critical comments on the manuscript.

\section{References}

Aleksandrowski, P., Kryza, R. \& Żaba, J., 1997. Kinematic data on major Variscan strike slip faults and shear zones in the Polish Sudetes, northeast Bohemian Massif. Geological Magazine 134, 727-739.

Badura, J., Krzyszkowski, D. \& Przybylski, B., 1998. Stratygrafia glin lodowcowych, liczba zlodowaceń i kierunki transportu lodowcowego w południowej części Przedgórza Sudeckiego (okolice Ząbkowic), Polska południowo-zachodnia [Till stratigraphy, number of glaciations and local glacial palaeotransport in the southern part of the Sudetic Foreland (Ząbkowice region), southwestern Poland]. Biuletyn PIG 385, 29-48.

Beschta, R.L. \& Jackson, W.L., 1979. The intrusion of fine sediments into a stable gravel bed. Journal of the Fisheries Research Board of Canada 36, 204-210.

Chachaj, J., Kida, J. \& Martini, A., 1984. Niektóre problemy sedymentacji kemowej w zachodniej części Sudetów Srodkowych. Acta Universitatis Wratislaviensis 655, Prace Instytutu Geograficznego, A3, 3-16.

Costa, J.E., 1988. Rheologic, geomorphic and sedimentologic differentiation of water floods, hyperconcentrated flows and debris flows. [In:] V.R. Baker, R.C. Kochel \& P.C. Patton (Eds): Flood geomorphology. Wiley, New York, 113-122.

Forbes, D.L., 1983. Morphology and sedimentology of a sinuous gravel-bed channel system: Lower Babbage River, Youkon coastal plain, Canada. International Association of Sedimentologists Special Publication 6, 195206.

Fraser, G.S. \& Cobb, J.C., 1982. Late Wisconsian proglacial sedimentation along the west Chicago moraine in northeastern Illinois. Journal of Sedimentary Petrology 52, 473-491.
Frostrick, L.E., Lucas, P.M. \& Reid, I., 1984. The infiltration of fine matrices into coarse-grained alluvial sediments and its implications for stratigraphical interpretation. Journal of the Geological Society 141, 85-94.

Giżejewski, J., 1973. Uwagi o terminologii i klasyfikacji struktur sedymentacyjnych osadów rzecznych [Comments on terminology and classification of structures in fluvial deposits]. Przeglad Geologiczny 11, 602-607.

Hein, F.J., 1984. Deep-sea and fluvial braided channel conglomerates: a comparison of two case studies. [In:] E.H. Koster \& R.J. Steele (Eds): Sedimentology of gravels and conglomerates. Canadian Society of Petroleum Geologists 10, 33-49.

Jahn, A., 1969. Terasy kemowe w Sudetach [Kame terraces in the Sudetes]. Folia Quaternaria 30, 17-22.

Kowalska, A., 2002. Rekonstrukcja środowisk sedymentacyjnych na podstawie sekwencji osadów glacilimnicznych w wybranych obszarach Sudetów [Reconstruction of the sedimentary environments on the basis of glaciolimnic sequences from some parts of the Sudetes]. Uniwersytet Wroctawski, Wydziat Przyrodniczy, Instytut Nauk Geologicznych 296 (unpublished).

Krzyszkowski, D. \& Allen, P., 2001. Quaternary stratigraphy and sediment deformation of the Jaroszów zone, Sudetic Foreland, southwestern Poland. [In:] D. Krzyszkowski et al. (Eds), Late Cainozoic stratigraphy and palaeogeography of the Sudetic Foreland, 2-24. Wind J. Wojewoda.

Krzyszkowski, D. \& Czech, A., 1995. Kierunki nasunięć lądolodu plejstoceńskiego na północnym obrzeżu Wzgórz Strzegomskich. [Pleistocene ice-sheet advances in the northern margin of the Strzegom Hills, Sudetic Foreland]. Przeglad Geologiczny 43, 647-651.

Krzyszkowski, D. \& Stachura, R., 1998. Late Quaternary valley formation and neotectonic evolution of the Wałbrzych Upland, Middle Sudeten MTS, southwestern Poland. Annales Societatis Poloniae 68, 23-60.

Lindner, L., 1970. Glacjalne tarasy marginalna lądolodu zlodowacenia środkowopolskiego na północno-zachodnim obrzeżeniu Gór Świętokrzyskich [Glacial marginal terraces of the Middle-Polish glaciation in the NW part of the Holy Cross Mountains]. Acta Geologica Polonica 2.

Maizels, J.K., 1977. Experiments on the origin of kettle holes. Journal of Glaciology 18, 291-303.

Maizels, J.K. 1987. Large-scale flood deposits associate with the formation of coarse-grained braided terrace sequences. Society of Economic Paleontologists and Mineralogists Special Publication 39, 135-148.

Maizels, J.K., 1993. Lithofacies variations within sandur deposits: the role of runoff regime, flow dynamics and sediment supply characteristic. Sedimentary Geology 85, 299-325.

Maizels, J.K., 1997. Jökulhlaup deposits in proglacial areas. Quaternary Science Review 16, 793-819.

McDonald, B.C. \& Banerjee, I., 1971. Sediments and bed forms on a braided outwash plain. Canadian Journal of Earth Sciences 8, 1282-1301.

Migoń, P., Krzyszkowski, D. \& Gogól, K., 1998. Geomorphic evolution of the mountains front of the Sudetes between Dobromierz and Paszowice and adjacent 
areas, with particular reference to the fluvial system. Geologia Sudetica 31, 289-305.

Mohrig, D., Heller, P.L., Paola, C. \& Lyons, W.J., 2000. Interpreting avulsion process from ancient alluvial sequences: Guadalope-Matarranya system (northern Spain) and Wasatch Formation (western Colorado). Geological Society of America Bulletin 112, 1787-1803.

Morison, S.R. \& Hein, F.J., 1987. Sedimentology of the White Channel gravels, Klondike area, Yukon Territory: fluvial deposits of the confined valley. [In:] F.G. Ethridge et al. (Eds), Recent developments in fluvial sedimentology. Society of Economic Paleontologists and Mineralogists Special Publication 39, 205-216.

Pisarska-Jamroży, M., 2006. Transitional deposits between the end moraine and outwash plain in the Pomeranian glaciomarginal zone of NW Poland: a missing component of ice-contact sedimentary models. Boreas 35, 126-141.

Russell, A.J. \& Marren, P.M., 1998. A Younger Dryas (Loch Lomond Stadial) jökulhlaup deposit, Fort Augustus, Scotland. Boreas 27, 231-242.

Siegenthaler, Ch. \& Huggenberger, P., 1993. Pleistocene Rhine gravel: deposits of a braided river system with dominant pool preservation. [In:] J.L. Best \& C.S. Bristow (Eds), Braided rivers, 147-162. Geological Society Special Publication 75.

Smith, N.D., 1974. Sedimentology and bar formation in the upper Kicking Horse river, a braided outwash stream. Journal of Geology 81, 205-223.
Szałamacha, J., 1956. Szczegótowa mapa geologiczna Sudetów w skali 1:25 000 ark. Janowice Wielkie [Detailed geological map of Sudetes Mountains, 1:25,000, sheet Janowice Wielkie). Polish Geological Institute, Warszawa.

Szałamacha, J., 1969. Objaśnienia do szczegótowej mapy geologicznej Sudetów w skali 1: 25000 ark. Janowice Wielkie [Explanations to the Detailed geological map of the Sudetes Mountains, 1:25,000, sheet Janowice Wielkie), 72 pp. Polish Geological Institute, Warszawa.

Szczepankiewicz, S. \& Szponar, A., 1978. Formy i osady kemowe $\mathrm{w}$ Polsce południowo-zachodniej [Kames and kame deposits in SW Poland]. Acta Universitatis Wratislaviensis 340, Prace Instytutu Geograficznego, A2, 3-19.

Walczak, W., 1957. Geneza form polodowcowych na przełęczach Sudetów Kłodzkich [The genesis of glacial forms in Kłodzkie Sudetes passes]. Czasopismo Geograficzne 28, 3-28.

Walczak, W., 1968. Sudety [The Sudetes Mountains]. Państwowe Wydawnictwo Naukowe, Warszawa.

Zieliński, T., 1992. Moreny czołowe Polski pótnocnowschodniej - osady $i$ warunki sedymentacj [Marginal moraines of NE Poland - sediments and depositional conditions]. Silesian University, Katowice, 96 pp.

Manuscript received 27 January 2010; revision accepted 12 May 2010. 